\title{
Factors Determine Cash Waqf Participation in Kedah, Malaysia: Perception from Students in Kolej University Insaniah
}

\begin{abstract}
Abobakr Ramadhan Salem Al-Harethi
Hadhramount University, Yemen

abobakralharethi@gmail.com

ABSTRACT

The advertisement made by the Bank Muamalat Malaysia Berhad (BMMB) was the major cause for a CashWaqf gained popularity in Malaysia partly, the first Islamic banking establishment to manage CashWaqf together with Perbadanan Wakaf Selangor (PWS). The aim of this study is to investigate the determinants of Cash Waqf participation from the Malaysian perspective. This study is based on three variables used to determine factors that affect CashWaqf participation in Malaysia. The three variables that are measured in this current study are religiosity, subjective norm, and attitude.used an attitude theory as a baseline theory. The data were collected through the distribution of questionnaires to IOO participants from Students at Kolej Insaniah Universiti. Based on multiple regression analysis and other statistical techniques, the findings of the study showed a significant relationship between religiosity, subjective norm, and attitude with CashWaqf participation. Given the results from the study, it highlights some limitations and suggestions for future studies that may be conducted in this scope.
\end{abstract}

Keywords: Cash Waqf, Religiosity, Subjective Norm, Attitude

\section{A. INTRODUCTION}

Waqf has a special property making it distinct from other types of tools which is its perpetuity property inherent within (Achmad, 2010). The CashWaqf idea is aimed at gathering public funds to be combined as a Waqf asset (endowment/financial capital) and managed by the way that it can make income stream besides keeping its original value to grow, or at least to maintaining its perpetuity. In addition, the proceeds from the investment of funds will be distributed to beneficiaries. CashWaqf plays a critical role in providing the public services needed by society(Ismail Abdel Mohsin, \& Muneeza, 2018).

Several modern scholars believe that contribution to Waqf in the form of Cash become inevitable.Ajfan (I985) explained that at the end of the I6th century, the idea of CashWaqf was entirely accepted by the whole Antonia and the European provinces of the Ottoman Empire, which was equally controlled some pieces of South Eastern Europe, North Africa, and the Middle East.

Submitted : January 4, 2019 - Revised: April 4, 2019 - Accepted :May 27, 2019

Hadhramount University, Yemen

E-Mail : abobakralharethi@gmail.com 
Waqf tools, as cash waqf, undeniably have great potential to improve the economy of Muslims, especially in financing social and cultural activities, the higher education sector is one from that (Anuar et al., 2019). Additionally, according to Abdul Khalim and Zakaria, (20I4), the system of cash waqf must provide various benefits and can do new waqf properties in the form of permanent property.

However, there are some factors like religiosity, subjective factors, and attitudes that have a profound influence on CashWaqf. These factors are playing a significant role in the payment process of CashWaqf. So, the present study aims at investigating how much impact these factors on the pay intention of the student for CashWaqf.

\section{B. THEORITICAL}

\section{a. Cashwaqf}

Generally, CashWaqf has great potential and a major role in helping higher education institutions in terms of helping students financially as well as institutions in their own right (Carabain \& Bekkers, 20II).In addition, Carabain, and Bekkers (20II) showed that Muslims have a relatively high rate of religious giving behavior.The two most critical kind of Islamic charitable giving are Waqf which known as a voluntary charitable gift and zakat also known as a compulsory charity (Idris \& Bidin, 2009).

\section{b. Religiosity}

In this study, the researcher determines the level of religiosity able to be one of the predictors to the intention of Waqif to participate in CashWaqf giving scheme. To illustrate, Muslims with higher levels of religiosity is believed would be more religious and their intention to participate in CashWaqf scheme is stronger than others. The effect of religiosity on behavioral intention has been scanty in the context of CashWaqf.

Islam honoured human as a creature and was entrusted with the task of worshiping Allah and his successor in the earth, and seeks to achieve a balance between his life in the world and his life in the Hereafter (Al Harethi,2019). Therefore, McDaniel and Burnett (1990) define religion as a belief in God accompanied by a commitment to follow principles believed to be set forth by God. In this study, perceived religiosity refers to the degree to which a person believes that participating in Cash Waqf would be of religious influence, as it is strongly encouraged in the religion of Islam in order to rich the mardatillah. Ong 
and Moschis (2006) and Mokhlis (2006) have documented the importance of religiosity in determining one's consumer behavior.

HI: There is positive relationship between religiosity and CashWaqf participation.

\section{c. Subjective Norm}

Ajzen (I99I) defines subjective norm as the perceived social pressure whether to perform the behavior. It refers to an individual's perception of relevant opinions from others on whether to perform a particular behavior. Previous studies such as Shih and Fang (2004), Lada et al. (2008) and Amin and Chong (20I I) have supported the significance effect of subjective norms on behavioral intention.

Explained in more detail, Lada et al. (2008) examine the effect of subjective norm on CashWaqf and discover a strong relationship between subjective norm and behavioral intention. This study demonstrates that "environment" can be of major factor explaining why person performs some behaviours. It is expected that subjective norm has an effect on CashWaqf participation, thus:

$\mathrm{H} 2$ : There is a positive relationship between subjective norm and CashWaqf.

\section{d. Attitude}

Attitude has long been identified as a construct that guides future behavior or the cause of the intention that ultimately leads to a particular behavior. In TRA, attitude is referred to as the evaluative effect of positive or negative feeling of individuals in performing a particular behavior (Fishbein and Ajzen, I975). The more recent definition of attitude is the degree of favourableness and unfavourableness of an individual's feeling towards a psychological object (Ajzen and Fishbein, 2000).

Many studies have shown the significant effect of attitude towards intention (Davis et al., 1989) general, the more favourable a person's attitude towards behavior, the more likely it is likely the person will want to engage in the behavior. Numerous studies have documented the significant relationship between attitude and intention (Shih \& Fang, 2004; Lada et al., 2008; Amin \& Chong, 20II). Hence, the next hypothesis is proposed is:

H3:attitude positively influences on intention of paying theCashWaqf

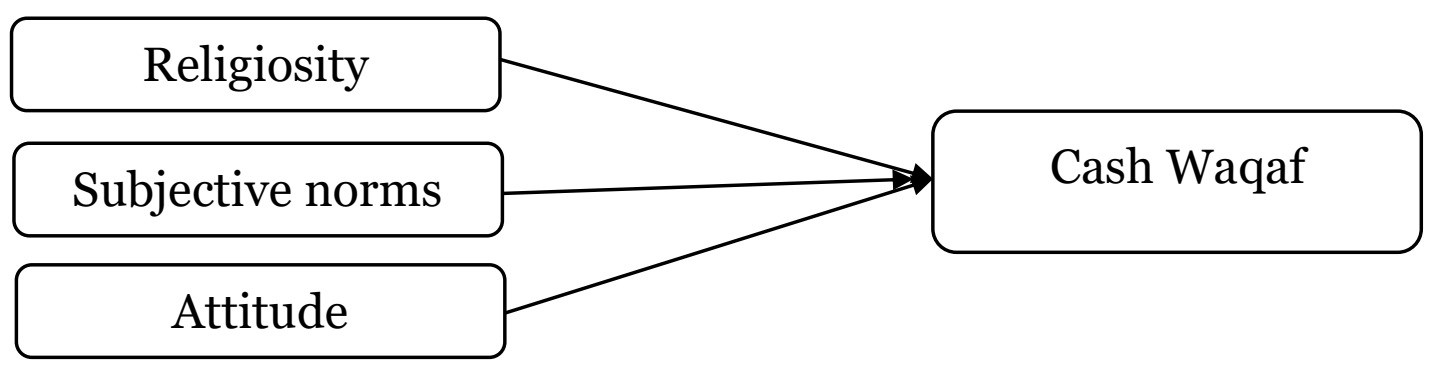


Factors Determine Cash Waqf Participation in Kedah, Malaysia: Perception from Students in Kolej University Insaniah

Abobakr Ramadhan Salem Al-Harethi

\section{METHODOLOGY}

For conducting the research, the data collected from primary data through a structured questionnaire with a scale from 100 respondents who are students of Kolej Insaniah Universiti, discussed of the factors that influence the intention to pay ofCash Waqaf, the following have been taken into consideration for the present study: religiosity, subjective norms, and the attitude.

The questionnaire was used in order to collect data. A total of II5 questionnaires provided, however only I00 were collected, the participants for this study were drawn from students at Kolej Insaniah Universiti in Kuala Ketil, Kedah, Malaysia. In the current study, the participation of students was voluntary. Most of the respondents were female, reaching $65 \%$ of the total respondents. The descriptive statistics are summed in Table I.

Table I:

Demographic results

\begin{tabular}{lccc}
\hline Profile & Description & Respondents & Percentage \\
\hline I. Gender & Male & 35 & $35 \%$ \\
& Female & 65 & $65 \%$ \\
2. Age & Less than 20 & 17 & $17 \%$ \\
& 2I-30 & 64 & $64 \%$ \\
& 3 I-40 & 19 & $19 \%$ \\
& 4I-50 & 0 & $0 \%$ \\
& Above 50 & 0 & $0 \%$ \\
& & & \\
& Ist year & 25 & $25 \%$ \\
2nd year & 28 & $37 \%$ \\
& 3rd Year & 37 & $10 \%$ \\
\hline
\end{tabular}




\section{RESULS AND DISCUSSION}

Table 2

Regression model

\begin{tabular}{llccc}
\hline & & $\beta$ & $t$-value & $p$-value \\
\hline & Religiosity & .317 & 1.985 & .050 \\
& Subjective norm & .206 & 2.064 & .042 \\
& Attitude & .332 & 2.047 & .043 \\
\hline$R$-square & & & .657 & \\
Adjusted $R$-squared & & .646 & \\
\hline
\end{tabular}

In order to investigate the hypothesis of this study, a regression test is conducted. Regression analysis was conducted to reveal how various factors influence CashWaqf participation. Obviously, religiosity is significantly correlated with CashWaqf participation $(t=2.064$, $p$-value $=0.050)$. This result is compatible with the previous studies (for example Osman, Mohammed, \& Amin, 20I4; Mokhlis,2006, and Ong and Moschis, 2006).

The results also show that subjective norm is significantly linked to CashWaqf participation $(t=1.985$, $p$-value $=0.042)$. This finding is supported the findings by Osman, Mohammed, \& Amin, 20I4; Amin and Chong, 20II, and Amin et al. 2010). Finally, attitude is significantly correlated with CashWaqf participation $(t=2.047, p$-value $=0.043)$., this result is consonant with the previous studies (for example, Osman, Mohammed, \& Amin, 20I4; Amin \& Chong, 20I I; Lada et al., 2008).

\section{E. CONCLUSION}

The current study aims to understand the factors determine CashWaqf participation in Kedah, Malaysia. Three factors investigated in this study (religiosity, subjective norm, and attitude) with CashWaqf Participation. An attitude theory used as a baseline theory, the study showed that there is a significant relationship between the three factors (religiosity, subjective norm, and attitude) and CashWaqf Participation. The study supported Osman, Mohammed, \& Amin, (20I4), research which found a significant relationship between attitude, subjective norm, perceived behavioral control, and religiosity with CashWaqf participation. The current study recommended for future studies to be conducted cover as much as possible from Malaysia 
Factors Determine Cash Waqf Participation in Kedah, Malaysia: Perception from Students in Kolej University Insaniah

Abobakr Ramadhan Salem Al-Harethi

\section{REFERANCES}

Abdul Khalim, M., \& Zakaria, N. H. (20I4). Peranan Media Massa Dalam Mempromosikan Saham Wakaf Johor. Pengurusan Jawhar, 8(I), I-I66. http://doi.org/http://dx.doi.org/I0.19193/0393-6384_20I6_I_3I

Achmad, Tohirin (20I0), The Cash Waqf for Empowering the Small Businesses. Paper presented at Seventh International Conference- The Tawhidi Epistemology: Zakat and Waqf Economy, Bangi 20I0, pp 486- 499

Ajzen, I., \& Fishbein, M. (2000). Attitudes and the attitude-behavior relation: Reasoned and automatic processes. European review of social psychology, $I I(\mathrm{I})$, I-33.https://scihub.tw/https://www.tandfonline.com/doi/abs/I0.I080/I47927799430 $\underline{00116}$

al Ajfan, A. (1985). Muhammad," al Waqf cala al masjid fi al Maghrib wa al Andalus"[Waqf on mosques in North West Africa and Andaluthia]. Dirasat fi al Iqtisad al Islami, International Center for Research in Islamic Economics, King Abd al Aziz University, Jeddah, 3I5-342.

Al Harethi, A. R. S. (2019). The Role of The Islamic Economy in Rationalizing Consumer Behavior. JIBER: Journal of Islamic Businnes and Economic Review, 2(I), I3-I7.

Amin, H., \& Chong, R. K. (20II). Is the theory of reasoned action valid for ArRahnu? An empirical investigation. Australian Journal of Basic and Applied Sciences, 5(10), 716-726.

Anuar, A. S., Bahari, Z., Doktoralina, C. M., Indriawati, F., \& Nugroho, L. (2019). The Diversity Of Waqf Implementations for Economic Development in HigherEducation. IKONOMIKA, 4(I),I3-34. http://ejournal.radenintan.ac.id/index.php/ikonomika/article/view/3808

Bidin, Z., Idris, K. M., \& Shamsudin, F. M. (2009). Predicting compliance intention on zakah on employment income in Malaysia: An application of reasoned action theory. Jurnal Pengurusan (UKM Journal of Management), 28.http://ejournal.ukm.my/pengurusan/article/viewFile/8 $95 / 825$

Carabain, C. L. and Bekkers, R. (201I), "Explaining differences in philanthropic behavior between Christians, Muslims, and Hindus in the Netherlands", Review of Religious Research, Vol. 53 No.4, pp. 4I9-440. 
IKONOMIKA

Volume 4, No I (2019)

http://dare.ubvu.vu.nl/bitstream/handle/I87I/33I4I/Carabain?sequenc $\underline{\mathrm{e}=2}$

Fishbein, M., \& Ajzen, I. (1975). Intention and Behavior: An introduction to theory and research.

Ismail Abdel Mohsin, M., \& Muneeza, A. (2018). Waqfcoin: an innovation to serve humanity.https://ikr.inceif.org/handle/INCEIF/2956

McDaniel, S. W., \& Burnett, J. J. (1990). Consumer religiosity and retail store evaluative criteria. Journal of the Academy of Marketing Science, I8(2), IOI-II2.https://scihub.tw/https://link.springer.com/article/I0.I007/BF02726426

Mokhlis, S. (2006). The influence of religion on retail patronage behaviour in Malaysia.https://dspace.stir.ac.uk/bitstream/I893/87/I/Mokhlis_PhD.p $\underline{\mathrm{df}}$

Ong, F. S., \& Moschis, G. P. (2006, July). Religiosity and consumer behavior: a crosscultural study. In International Conference on Business and Information (Vol. 3, pp. I-I3).

Osman, A. F., Mohammed, M. O., \& Amin, H. (20I4). An analysis of Cash Waqf participation among young intellectuals.

Suryanto, T., Purnamasari, F., \& Kurniawan, M. (2018). Tax Revenue and Disparity: How to Improvement Income Inequality in Islamic Perspective. Asian Journal of Social Sciences and Management Studies, 5(2), 65-7I.

Shih, Y. Y., \& Fang, K. (2004). The use of a decomposed theory of planned behavior to study Internet banking in Taiwan. Internet research, I4(3), 2I3223.https://www.emeraldinsight.com/doi/pdfplus/I0.II08/I06622404 $\underline{10542643}$ 